\title{
ANALISIS PEMERIKSAAN PAJAK DALAM RANGKA OPTIMALISASI PENERIMAAN NEGARA DI SEKTOR PERPAJAKAN
}

\author{
Bambang Irawan \& Teguh Budiono \\ Fakultas Ilmu Administrasi, Institut Ilmu Sosial dan Manajemen STIAMI \\ bbgirw7980@gmail.com
}

\begin{abstract}
Abstrak. Tujuan dari penelitian ini adalah untuk mengetahui bagaimanakah pemeriksaan pajak dapat mengoptimalkan penerimaan negara di sektor perpajakan, faktor-faktor apa yang menjadi penghambat dalam melaksanakan pemeriksaan pajak, dan solusi apa saja yang dapat direkomendasikan dalam mengatasi hambatan-hambatan tersebut. Penelitian ini menggunakan pendekatan kualitatif, dengan melakukan wawancara, observasi dan studi dokumen. Adapun yang menjadi informan adalah stakeholder yang memahami pelaksanaan pemeriksaan pajak yang berjumlah enam orang informan. Pemeriksaan Pajak yang dapat mengoptimalkan penerimaan negara di sektor perpajakan dipengaruhi oleh beberapa faktor, yaitu Peraturan perundang-undangan yang memberikan kejelasan, kepastian dan kesederhanaan yang dapat mengurangi sengketa peraturan, kebijakan pemerintah dalam mengimplementasikan peraturan, Sistem administrasi yang memberikan fungsi penyuluhan, pelayanan dan pengawasan serta sistem informasi mendukung, Pelayanan prima dalam pelaksanaan pemeriksaan pajak, tingkat kesadaran dan pemahaman Wajib Pajak terhadap peraturan perpajakan, dan fungsional Pemeriksa yang profesional dan berintegritas. Terdapat beberapa hambatan dalam pelaksanaan pemeriksaan pajak, yaitu target penerimaan negara di sektor perpajakan yang tidak realistis, peraturan perpajakan yang multi tafsir, terbatasnya data eksternal dan belum terintegrasinya data internal yang dimiliki, beban pemeriksaan rutin yang tinggi, kurangnya kuantitas dan kualitas Fungsional Pemeriksa Pajak, dan kurangnya dukungan kendaraan dinas dan dana operasional. Solusi untuk mengatasi hambatan-hambatan tersebut yaitu penyusunan target penerimaan harus lebih realistis, peraturan perpajakan harus disusun dengan memperhatikan prinsip kejelasan, kepastian dan kesederhanaan, optimalisasi PP Nomor 31 tahun 2012, mengurangi pemeriksaan rutin, Penambahan kuantitas dan kualitas Fungsional Pemeriksa Pajak, dan penyediaan kendaraan dinas.
\end{abstract}

Keywords: Pemeriksaan Pajak, Penerimaan Negara, Hambatan, Solusi

\begin{abstract}
The purpose of this study was to determine how the tax audit can optimize revenues in the tax sector, factors that become an obstacle in carrying out tax audits, and any solution that could be recommended to overcome such obstacles. This study used a qualitative approach, by conducting interviews, observation and document study. The informants in this study are stakeholders who understand the implementation of a tax audit as many as six informants. Tax audits to optimize state income in the taxation sector is influenced by several factors, namely legislation which provides clarity, certainty and simplicity that can reduce the dispute regulations, government policy in implementing regulations, administrative system that provides counseling function, care and supervision as well information systems support, excellent service in the implementation of a tax audit, the level of awareness and understanding of the taxpayer to the tax laws, and functional Examiner and professional integrity. There are several obstacles to the implementation of the tax audit, include unrealistic state revenue target in the taxation sector, tax laws have multiple interpretations, limited external data and unintegrated internal data held, the burden of routine inspections are high, the lack of quantity and quality Functional Tax Audit, and lack of official vehicles and operating funds. Solutions to overcome these obstacles, include preparation of the revenue target should be more realistic, tax laws should be drawn with regard to
\end{abstract}


principles of clarity, certainty and simplicity, optimization of Government Regulation No. 31 of 2012, reducing routine inspection, addition of the quantity and quality Functional Tax Audit, and the provision of vehicles service.

Keywords: Tax Audit, National Revenue, Obstacle, Solution

\section{Pendahuluan}

Pajak merupakan tulang punggung penerimaan negara di dalam postur Anggaran Penerimaan dan Belanja Negara (APBN). Berdasarkan Budget in Brief APBNPerubahan Tahun 2015 (APBN-P Tahun 2015), target penerimaan dari sektor perpajakan (pajak, bea dan cukai) sebesar Rp1.489,3 Triliun atau $84,54 \%$ dari total APBN-PTahun 2015sebesar Rp1.761,6
Triliun. Target penerimaan perpajakan pada APBN-P Tahun 2015 naik sebesar 7,92\% dari target penerimaan perpajakan pada APBN Tahun 2015sebesar Rp1.380 Triliun. Namun, sejak tahun 2010 sampai dengan 2014, penerimaan perpajakan tidak pernah mencapai target. Realisasi penerimaan perpajakan di tahun 2010 sampai dengan 2014 dapat dilihat pada tabel berikut:

Tabel 1. Realisasi Penerimaan Perpajakan Tahun 2010 s.d. 2014

\begin{tabular}{|c|r|r|r|}
\hline Tahun & Realisasi ${ }^{\star}$ ) & \multicolumn{1}{|c|}{ Target $^{\star}$ ) } & \% Pencapaian \\
\hline 2010 & 723,30 & 743,32 & $97,3 \%$ \\
\hline 2011 & 873,87 & 878,68 & $99,5 \%$ \\
\hline 2012 & 980,52 & $1.016,24$ & $96,5 \%$ \\
\hline 2013 & $1.077,31$ & $1.148,36$ & $93,8 \%$ \\
\hline 2014 & $1.146,80$ & $1.246,10$ & $92,0 \%$ \\
\hline
\end{tabular}

*) dalam triliun rupiah

Sumber: LKPP Tahun 2013 Audited dan Realisasi APBN Tahun 2014

Pencapaian penerimaan tertinggi dari tahun 2010 s.d. 2014 berada di tahun 2011, yaitu sebesar $99,5 \%$, sedangkan pencapaian terendah berada di tahun 2014 yaitu sebesar 92\%. Pertumbuhan realisasi penerimaan perpajakan untuk tahun 2014 sebesar $6,45 \%$, sedangkan pertumbuhan tahun 2013 sebesar $9,87 \%$. Artinya, pertumbuhan tahun 2014 turun sebesar $3,42 \%$ dari pertumbuhan tahun 2013.

Upaya yang dapat dilakukan oleh Direktorat Jenderal Pajak dalam meningkatkan penerimaan perpajakan adalah melalui penegakan hukum (law enforcement) yang salah satunya melalui pemeriksaan. Kegiatan pemeriksaan sebagaimana diatur dalam Pasal 29 Undang-Undang Nomor 6 Tahun 1983 tentang Ketentuan Umum dan Tata Cara Perpajakan sebagaimana telah beberapa kali diubah terakhir dengan Undang-Undang Nomor 16 Tahun 2009, dapat menjadi salah satu sarana penegakan hukum dalam rangka menguji kepatuhan pemenuhan kewajiban perpajakan.

Realisasi pemeriksaan yang dilakukan oleh Direktorat Jenderal Pajak pada tahun 2011-2013 mengalami peningkatan. Pada tahun 2011, Laporan hasil Pemeriksaan yang diselesaikan sebanyak 61.351 dengan nilai $\mathrm{Rp}$. 11.200 Miliar, di tahun 2012 dari sisi jumlah menurun yaitu menjadi 55.666 laporan namun nilainya meningkat menjadi Rp. 14.240 Miliar, sedangkan di tahun 2013 meningkat dengan nilai Rp. 20.740 Miliar. Peningkatan penerimaan dari pemeriksaan seharusnya berkorelasi positif dengan penerimaan pajak seluruhnya.

Sejak tahun 2002, Direktorat Jenderal Pajak telah melakukan reformasi perpajakan dalam bentuk reformasi regulasi institusi (infrastuktur dan administrasi perpajakan). Dalam bidang pemeriksaan, Direktorat Jenderal Pajak senantiasa melakukan penyesuaian terhadap berbagai ketentuan yang mengatur mengenai pemeriksaan pajak dalam 
rangka memberikan kepastian hukum dan untuk lebih memberikan rasa keadilan kepada Wajib Pajak.

Sebagai sistem dan sarana, penerapan sistem administrasi perpajakan modern sangat tergantung pelaksanaannya, terutama bidang perpajakan yang sangat rentan akan fraud serta Korupsi, Kolusi, dan Nepotisme (KKN). Semangat perubahan dalam penerapan sistem administrasi perpajakan modern sebagai wujud reformasi administrasi perpajakan hendaknya dapat meningkatkan integritas dan moral pegawai pajak sehingga dapat mendorong komitmen Wajib Pajak dalam pemenuhan kewajiban perpajakannya serta meningkatkan kepercayaan masyarakat terhadap administrasi perpajakan di Indonesia. Dalam kaitannya dengan pemeriksaan pajak, diharapkan proses pemeriksaan dapat berimbang, transparan dan memberikan rasa keadilan serta kepastian hukum kepada Wajib Pajak.

Pelaksanaan pemeriksaan pajak (tax audit) dewasa ini banyak mendapat perhatian karena perannya yang cukup penting dalam melakukan pengujian kepatuhan pemenuhan kewajiban perpajakan (compliance audit), yang merupakan salah satu sarana untuk melihat tingkat kepatuhan dan menentukan besarnya kewajiban perpajakan yang harus dipikul oleh Wajib Pajak. Pelaksanaan pemeriksaan pajak dituntut harus memberikan suatu deterrent effect (efek jera) sehingga dapat mengurangi kemungkinan terjadinya penyelewengan dan/atau penghindaran pajak oleh pihak lain. Penegakan hukum dalam perpajakan mempunyai korelasi yang positif dengan kesuksesan penerimaan pajak, artinya pelaksanaan penegakan hukum pajak secara tegas dan konsisten khususnya di bidang pemeriksaan pajak dan faktor-faktor penghambat dalam pelaksanaan pemeriksaan dapat diatasi, maka akan mampu menciptakan kepatuhan yang tinggi dan akan bermuara pada peningkatan penerimaan dari sektor pajak.

Penelitian ini bertujuan untuk mengetahui bagaimanakah pemeriksaan pajak yang dapat mengoptimalkan penerimaan negara di sektor perpajakan, faktor-faktor apa yang menjadi penghambat dalam melaksanakan pemeriksaan pajak, dan solusi apa saja yang dapat direkomendasikan dalam mengatasi hambatan-hambatan tersebut.

\section{Kajian Pustaka \\ Optimalisasi Penerimaan Negara}

Menurut Hutagaol (2007: 74), agar sistem self assessment berjalan sesuai ketentuan, Direktorat Jenderal Pajak melaksanakan 3 (tiga) fungsi, yaitu penyuluhan (disseminations), pelayanan (service) dan pengawasan (law enforcement). Di bidang pengawasan, terdapat 3 (tiga) pilar yaitu pemeriksaan (audit), penyidikan (investigation) dan penagihan pajak (tax collection). Pemeriksaan pajak menurut Hutagaol (2007: 64) adalah:

Pemeriksaan pajak diartikan sebagai serangkaian kegiatan untuk mencari, mengumpulkan, mengolah data, informasi dan atau keterangan lainnya yang berguna untuk menguji kepatuhan Wajib Pajak (taxpayer's compliance) di dalam pemenuhan kewajibannya di bidang perpajakan dan tujuan lain (other purpose).

Berdasarkan kedua pengertian tersebut, ada dua tujuan dilakukan pemeriksaan pajak, yaitu menguji kepatuhan pemenuhan kewajiban perpajakan, dan/atau tujuan lain dalam rangka melaksanakan ketentuan peraturan perundang-undangan perpajakan.

Menurut Hutagaol (2007: 73-74), tujuan pemeriksaan pajak menguji kepatuhan pemenuhan kewajiban perpajakan (misal kewajiban pelaporan dan pembayaran pajak baik secara substansi maupun formal) dan tujuan lainnya (misalnya pemberian Nomor Pokok Wajib Pajak (NPWP) secara jabatan, pencabutan NPWP, dalam proses keberatan, pencocokan data dan atau alat keterangan, penentuan daerah terpencil). Menurut Rahayu (2010: 246) pemeriksaan untuk tujuan menguji kepatuhan wajib pajak, dilakukan dalam hal: (1) SPT menunjukkan kelebihan pembayaran pajak, termasuk yang telah diberikan pengembalian pendahuluan kelebihan pajak; (2) SPT tahunan pajak penghasilan menunjukkan rugi; (3) SPT tidak disampaikan atau disampaikan tidak pada waktu yang telah ditetapkan; (4) SPT yang memenuhi kriteria 
seleksi yang ditentukan oleh Direktur Jenderal Pajak; dan (5) Ada indikasi kewajiban perpajakan selain kewajiban tersebut pada angka 3 tidak dipenuhi.

Menurut Rahayu (2010: 262), pemeriksaan pajak dapat dibedakan berdasarkan ruang lingkup cakupannya, yaitu terdiri dari pemeriksaan lapangan dan pemeriksaan kantor. Pemeriksaan lapangan yaitu pemeriksaan yang dilakukan terhadap wajib pajak di tempat kedudukan/kantor, tempat usaha (pabrik), atau pun pekerjaan bebas, domisili atau tempat tinggal, sedangkan pemeriksaan kantor yaitu pemeriksaan yang dilakukan terhadap wajib pajak di kantor unit pemeriksaan.

Menurut Rahayu (2010: 255-256) pelaksanaan pemeriksaan didasarkan pada pedoman pemeriksaan pajak yang meliputi Pedoman umum Pemeriksaan Pajak, Pedoman Pelaksanaan Pemeriksaan Pajak, dan pedoman Laporan Pemeriksaan Pajak. (1) Pedoman Umum Pemeriksaan. Pemeriksaan pajak dilaksanakan oleh Pemeriksa Pajak yang: (1.a) telah mendapat pendidikan teknis yang cukup dan memiliki keterampilan sebagai Pemeriksa Pajak; (1.b) bekerja jujur, bertanggung jawab, penuh pengabdian, bersikap terbuka, sopan dan obyektif, serta menghindari diri dari perbuatan tercela; dan (1.c) menggunakan keahliannya secara cermat dan seksama serta memberikan gambaran yang sesuai dengan keadaan sebenarnya tentang Wajib Pajak. (2) Pedoman Pelaksanaan Pemeriksaan. Pelaksanaan pemeriksaan harus didahului dengan persiapan yang baik, sesuai dengan tujuan pemeriksaan, dan mendapat pengawasan yang seksama. (2.a) Luas pemeriksaan ditentukan berdasarkan petunjuk yang diperoleh yang harus dikembangkan melalui pencocokkan data, pengamatan, tanya jawab, dan tindakan lain berkenaan dengan pemeriksaan; dan (2.b) Pendapat dan kesimpulan Pemeriksa Pajak harus didasarkan pada temuan yang kuat dan berlandaskan ketentuan peraturan perundang-undangan perpajakan. (3) Pedoman Pelaporan Pemeriksaan. (3.a) Laporan pemeriksaan pajak disusun secara ringkas, jelas, memuat ruang lingkup sesuai dengan tujuan pemeriksaan, memuat kesimpulan Pemeriksa Pajak yang didukung temuan yang kuat tentang ada atau tidak adanya penyimpangan terhadap peraturan perundang-undangan perpajakan, dan memuat pula pengungkapan informasi lain yang terkait; (3.b) Laporan pemeriksaan pajak yang berkaitan dengan pengungkapan penyimpangan SPT harus memperhatikan Kertas kerja Pemeriksaan antara lain mengenai: (3.b.1) berbagai faktor perbandingan; (3.b.2) nilai absolut dari penyimpangan; (3.b.3) sifat dari penyimpangan; (3.b.4) petunjuk atau temuan adanya penyimpangan; (3.b.5) pengaruh penyimpangan; dan (3.b.6) hubungan dengan permasalahan lainnya; dan (3.c) Laporan pemeriksaan pajak harus didukung oleh daftar yang lengkap dan rinci sesuai dengan tujuan pemeriksaan.

\section{Optimalisasi Penerimaan Negara}

Menurut Suparmoko (2012: 127), definisi penerimaan negara adalah:

Penerimaan negara diartikan sebagai penerimaan pemerintah dalam arti yang seluas-luasnya yaitu meliputi penerimaan pajak, penerimaan yang diperoleh dari hasil penjualan barang dan jasa yang dimiliki dan dihasilkan oleh pemerintah, pinjaman pemerintah, mencetak uang, dan sebagainya.

Rahayu (2010: 54) membagi penerimaan negara menurut sebagai berikut: (1) Penerimaan dalam negeri, terdiri dari: (1.a) Penerimaan Migas terdiri dari: (1.a.1) Minyak Bumi, dan (1.a.2) Gas Alam; (1.b) Penerimaan Non Migas terdiri dari: (1.b.1) Pajak Penghasilan; (1.b.2) Pajak Pertambahan Nilai; (1.b.3) Bea Masuk; (1.b.4) Cukai; (1.b.5) Pajak Ekspor; (1.b.6) Pajak Bumi dan Bangunan; (1.b.7) Pajak Lainnya; (1.b.8) Penerimaan Bukan Pajak; dan (1.b.9) Laba Bersih Minyak. (2) Penerimaan pembangunan terdiri dari: (2.a) Bantuan Program; dan (2.b) Bantuan Proyek.

Menurut pandangan Rahayu (2010: 2729) terdapat beberapa faktor yang berperan penting dalam mempengaruhi dan menentukan optimalisasi pemasukan dana ke Kas Negara melalui pemungutan pajak, yaitu: (1) Kejelasan, kepastian, dan kesederhanaan peraturan perundang-undangan perpajakan; (2) 
Kebijakan pemerintah dalam mengimplementasikan undang-undang perpajakan; (3) Sistem administrasi perpajakan yang tepat; (4) Pelayanan; (5) Kesadaran dan pemahaman warga negara; dan (6) Kualitas petugas pajak (intelektual, keterampilan, integritas, moral tinggi).

Terkait peran administrasi perpajakan, Rahayu (2010: 93) menyatakan bahwa administrasi perpajakan berperan penting dalam sistem perpajakan di suatu negara. Suatu negara dapat dengan sukses mencapai sasaran yang diharapkan dalam menghasilkan penerimaan pajak yang optimal karena administrasi perpajakannya mampu dengan efektif melaksanakan sistem perpajakan di suatu negara yang dipilih. Untuk memastikan terlaksananya administrasi perpajakan, maka faktor pemeriksaan sangat penting untuk memastikan penerimaan negara.

\section{Kerangka Pemikiran}

Pajak merupakan tulang punggung penerimaan negara dalam Anggaran Pendapatan dan Belanja Negara (APBN). Pada APBN-Perubahan Tahun 2015, penerimaan perpajakan ditargetkan sebesar Rp1.489,3 Triliun atau $84,5 \%$ dari total target penerimaan negara sebesar Rp1.761,6 Triliun. Dengan peningkatan target sebesar $19,5 \%$ dari target tahun 2014 sebesar Rp1.246,1 Triliun, dibutuhkan suatu upaya yang optimal dari Direktur Jenderal Pajak untuk mencapai target penerimaan tersebut.

Perpajakan di Indonesia menggunakan sistem self assessment dalam pemungutannya. Sistem self assestment memberikan kepercayaan kepada Wajib Pajak untuk menghitung, menyetor dan melaporkan pajak yang terutang melalui Surat Pemberitahuan (SPT) ke Direktur Jenderal Pajak. Sistem self assessment membutuhkan voluntary compliance, karena itu peran aktif Wajib Pajak dibutuhkan dalam melaksanakan pemenuhan kewajiban perpajakannya.

Konsekuensi diterapkannya sistem self assessment adalah dibutuhkan suatu sarana untuk dapat menguji kebenaran Surat Pemberitahuan yang disampaikan oleh Wajib Pajak. pengujian kebenaran SPT Tahunan

diperlukan karena untuk kepastian hukum, SPT dianggap benar sepanjang tidak ada data dan/atau keterangan lainnya yang menyatakan bahwa SPT tersebut tidak benar.

Salah satu sarana yang dapat digunakan Direktur Jenderal Pajak dalam menguji kepatuhan pemenuhan kewajiban perpajakan adalah melalui pemeriksaan pajak. Pemeriksaan pajak merupakan salah satu dari tiga pilar-pilar penegakan hukum (law enforcement), yaitu pemeriksaan pajak (tax audit), penyidikan pajak (tax investigation) dan penagihan pajak (tax collection).

Pemeriksaan pajak berperan dalam menangani Wajib Pajak yang diduga melakukan penggelapan pajak (tax evasion). Dalam praktik tax evasion ini tentunya banyak modus dan kasusnya. Inilah sebabnya profesionalisme dan integritas pemeriksa pajak sangat dibutuhkan dalam menangani kasuskasus tax evasion.

Pelaksanaan pemeriksaan pajak (tax audit) mendapatkan peran yang penting dalam melakukan pengujian kepatuhan pemenuhan kewajiban perpajakan (compliance audit), yang merupakan salah satu sumber penting dalam pengambilan keputusan untuk melihat tingkat kepatuhan dan menentukan besarnya kewajiban perpajakan yang harus dipikul oleh Wajib Pajak, sehingga pelaksanaan pemeriksaan pajak dituntut harus memberikan suatu efek penggentar (deterrent effect). Efek penggentar tersebut diharapkan bermuara pada meningkatnya kepatuhan pemenuhan kewajiban perpajakan dan meningkatnya kontribusi terhadap penerimaan negara dari sektor perpajakan sehingga penerimaan pajak dapat tergali secara optimal. Pemeriksaan pajak dalam rangka penegakan hukum dalam perpajakan diharapkan mempunyai korelasi yang positif dengan kesuksesan penerimaan pajak, artinya pelaksanaan penegakan hukum pajak secara tegas dan konsisten akan mampu menciptakan kepatuhan yang lebih baik dari Wajib Pajak dan akan bermuara pada peningkatan penerimaan pajak.

\section{Metode Penelitian}


Creswell dalam Silalahi (2012: 77) mendefinisikan penelitian kualitatif sebagai suatu proses penyelidikan untuk memahami masalah sosial berdasarkan pada penciptaan gambaran holistik lengkap yang dibentuk dengan kata-kata, melaporkan pandangan informan secara terperinci, dan disusun dalam sebuah latar alamiah. Penelitian ini menggunakan paradigma naturalistik dengan tujuan untuk grasping or understanding of the meaning 'memahami secara mendalam makna yang terkandung' dan kategori-kategori atau entitas-entitas yang berhubungan dengan pemeriksaan pajak dalam rangka mengoptimalkan penerimaan negara.

Informan adalah individu yang diyakini mempunyai dan menguasai informasi tentang topik penelitian. Dalam penelitian kualitatif, sampling harus ditentukan sebelumnya untuk tujuan tertentu (purposive sampling). Informan yang dipilih dalam penelitian ini antara lain: (a) Informan pertama (If 1) adalah Bapak Dr. A. Anshari Ritonga, SH., MH sebagai Tenaga Ahli Menteri Keuangan Bidang Pajak sekaligus mantan Direktur Jenderal Pajak; (b) Informan kedua (If 2) adalah Bapak Prof. Gunadi sebagai Akademisi; (c) Informan ketiga (If 3) adalah Bapak Herry Setyawan sebagai Kepala Bagian Fasilitasi Analisa dan Konsultasi Sekretariat Komite Pengawas Perpajakan; (d) Informan keempat (If 4) adalah Bapak Fatah Yasin sebagai Kepala Subbagian Fasilitasi Analisa Pajak Sekretariat Komite Pengawas Perpajakan; (e) Informan Kelima (If 5) adalah Bapak Sigit Widayanto, SE sebagai Ketua Tim Fungsional Pemeriksa Pajak di KPP Penanaman Modal Asing Tiga; dan (f) Informan keenam (If 6) adalah Bapak Maulana Fatah Hidayatullah sebagai Wajib Pajak (Tax Supervisor di PT. Semen Tonasa).

Dalam teknik pengumpulan data ini, penulis melakukan wawancara mendalam dengan pertanyaan terbuka kepada informan yang dilakukan untuk mendapatkan informasi tentang isu-isu terkait dengan penelitian, yang dalam hal ini terkait dengan pemeriksaan pajak. Hasil wawancara perlu dicatat atau direkam agar dapat menjadi informasi yang tersusun secara sistematis sebagai penjelasan atas masalah yang sedang diteliti. Pada teknik Direct Observation atau observasi langsung peneliti mengamati langsung proses pelaksanaan tugas dari Direktorat Jenderal Pajak terutama terkait dengan pemeriksaan pajak. Dengan teknik written document penulis akan membahas berbagai korespondensi, dan surat-surat yang terkait dengan fokus penelitian yang dapat menjelaskan fenomena sosial yang sedang diteliti.

Penelitian ini dilakukan pada Bagian Fasilitasi Analisa dan Konsultasi Sekretariat Komite Pengawas Perpajakan dan Direktorat Jenderal Pajak. Jadwal penelitian dilakukan pada bulan Februari -sampai dengan Agustus 2015.

\section{Temuan dan Pembahasan}

Berdasarkan hasil penelitian dan analisa data yang dilakukan, ditemukan bahwa :

\section{Pemeriksaan Pajak yang Dapat Mengoptimalkan Penerimaan Negara di Sektor Perpajakan}

Pemeriksaan pajak sebagai salah satu pilar law enforcement memiliki peran yang dapat meningkatkan penerimaan pajak. Namun, pemeriksaan pajak yang seperti apa yang dapat mengoptimalkan penerimaan pajak?

Faktor-faktor yang harus terpenuhi agar pemeriksaan pajak dapat mengoptimalkan penerimaan negara antara lain:

\section{Kejelasan, Kepastian dan Kesederhanaan Peraturan Perundang-undangan.}

Peraturan perpajakan yang ideal dapat memberikan kejelasan, kepastian hukum dan kesederhanaan sehingga tidak menimbulkan multi tafsir sehingga dapat menjadi sengketa peraturan, baik di internal DJP maupun antara DJP dengan Wajib Pajak. Pasal 16 ayat (3), Pasal 17B ayat (2) dan Pasal 26 ayat (5) UU KUP memberikan kepastian hukum terhadap status permohonan yang diajukan oleh Wajib Pajak apabila telah melewati jangka waktu yang telah ditetapkan dalam peraturan perundang-undangan sehingga Wajib Pajak mendapatkan kejelasan jawaban atas permohonan yang diajukan. Pasal 17B UU KUP memberikan kepastian jangka waktu penyelesaian permohonan pengembalian kelebihan pembayaran pajak yang diproses 
dengan pemeriksaan pajak. Dengan adanya jangka waktu tersebut, maka pemeriksaan pajak harus diselesaikan sebelum jangka waktu tersebut berakhir. Apabila jangka waktu tersebut terlewati, maka permohonan Wajib pajak tersebut telah memiliki kepastian hukum, yaitu dianggap dikabulkan oleh DJP. Dengan peraturan perundang-undangan yang jelas, pasti dan sederhana akan mengurangi sengketa peraturan dan akan mendorong Wajib Pajak untuk melaksanakan hak dan kewajibannya dengan baik sehingga tingkat kepatuhan akan meningkat yang pada akhirnya akan meningkatkan penerimaan.

\section{Kebijakan Pemerintah dalam Mengimplementasikan Undang-Undang Perpajakan.}

Peraturan Menteri Keuangan (PMK) Nomor 17/PMK.03/2013 tentang Tata Cara Pemeriksaan, Peraturan Direktur Jenderal Pajak Nomor Per-23/PJ/2013 tentang Standar Pemeriksaan, Surat Edaran Direktur Jenderal Pajak Nomor SE-126/PJ/2010 tentang Pedoman Penyusunan Rencana Pemeriksaan (Audit Plan) Untuk Menguji Kepatuhan pemenuhan Kewajiban Perpajakan, Surat Edaran Direktur Jenderal Pajak Nomor SE04/PJ/2012 tentang Pedoman Penyusunan Program Pemeriksaan Untuk Menguji Kepatuhan Pemenuhan Kewajiban Perpajakan, Surat Edaran Direktur Jenderal Pajak Nomor SE-09/PJ/2012 tentang Pedoman Penyusunan Laporan Hasil Pemeriksaan Untuk Menguji Kepatuhan Pemenuhan Kewajiban Perpajakan, merupakan implementasi dari Pasal 29 dan 31 UU KUP yang mengatur kewenangan DJP untuk melakukan pemeriksaan pajak. Peraturan-peraturan pelaksanaan ini mengatur alur pelaksanaan pemeriksaan secara rinci sebagaimana digambarkan pada Gambar 5, termasuk jangka waktu pemeriksaan, bentuk dan isi dokumen yang terkait dengan pemeriksaan, peminjaman dokumen, permintaan keterangan dan hal-hal teknis lainnya yang tidak diatur dalam pasal 29 dan 31 UU KUP. Prosedur yang diatur dalam peraturan pelaksanaan ini memberikan equal treatment bagi DJP dan Wajib Pajak. Bagi DJP, peraturan pelaksanaan ini menjadi pedoman (guidance) dalam melaksanakan pemeriksaan, sedangkan bagi Wajib Pajak dapat mengetahui secara transparan proses pemeriksaan, hak dan kewajiban yang harus dilaksanakan sehingga dapat meminimalisasi kemungkinan penyalahgunaan wewenang (abuse of power). Kebijakan pemerintah dalam mengimplementasikan peraturan perundangundangan secara rinci, transparan dan equal treatment diharapkan akan meningkatkan kepatuhan Wajib Pajak dalam melaksanakan kewajibannya.

\section{Sistem Administrasi Perpajakan yang Tepat}

Sistem self assessment memberikan kepercayaan kepada Wajib Pajak dalam melaksanakan kewajiban perpajakannya, yaitu menghitung, menyetor dan melaporkan pemenuhan kewajibannya dalam bentuk Surat Pemberitahuan (SPT). Dalam sistem ini, SPT yang disampaikan oleh Wajib Pajak dianggap benar sepanjang tidak ada data lainnya yang membuktikan bahwa SPT tersebut salah.

Dalam melakukan pengujian SPT, dibutuhkan sistem administrasi yang tepat. Sistem administrasi ini meliputi DJP sebagai administrator perpajakan dan sistem informasi yang mendukung pelaksanaan fungsi DJP. Fungsi DJP dalam administrasi perpajakan dapat dibagi menjadi tiga, yaitu penyuluhan, pelayanan dan pengawasan. Sebelum reformasi perpajakan, fungsi-fungsi ini diwujudkan dalam tiga unit vertikal di DJP yaitu penyuluhan direpresentasikan oleh Kantor Pelayanan dan Pengamatan Potensi Perpajakan (KP4) yang sekarang menjadi Kantor Pelayanan, Penyuluhan dan Konsultasi Perpajakan (KP2KP), pelayanan direpresentasikan oleh Kantor Pelayanan Pajak (KPP) dan pengawasan direpresentasikan oleh Kantor Pemeriksaaan Pajak (Karikpa) yang sudah melebur menjadi KPP Pratama. Fungsifungsi ini disusun secara sistematis sehingga fungsi pertama DJP adalah memberikan penyuluhan kepada Wajib Pajak terkait hak dan kewajibannya, kemudian DJP berkewajiban memberikan pelayanan dan fasilitas kepada WP dalam pelaksanaan pemenuhan kewajiban perpajakannya. Untuk menguji kepatuhan pemenuhan kewajiban 
perpajakan Wajib Pajak, DJP melaksanakan fungsi pengawasan yang salah satunya melalui pemeriksaan pajak.

Sistem informasi yang dimiliki oleh DJP digunakan untuk mendukung pelaksanaan tugas dan fungsi DJP, termasuk dalam pemeriksaan pajak. Sistem informasi ini diharapkan dapat membantu DJP untuk menyeleksi Wajib Pajak yang akan diperiksa. Dengan indikator-indikator tertentu, sistem informasi diharapkan dapat memilih Wajib Pajak yang terindikasi tidak patuh dan memiliki tax gap yang tinggi sehingga pemeriksaan yang dilakukan dapat menghasilkan penerimaan negara yang tinggi.

\section{Pelayanan Prima}

Pelayanan prima (service excellent) adalah pelayanan yang melebihi dari apa yang diharapkan oleh wajib Pajak. Sekilas, pemeriksaan pajak tidak ada kaitannya dengan pelayanan prima. Namun, anggapan tersebut kurang tepat. Dengan pelayanan prima yang diberikan oleh Fungsional Pemeriksa kepada Wajib Pajak saat melaksanakan pemeriksaan pajak, maka pelaksanaan pemeriksaan dapat mencapai tujuan yang diinginkan karena Wajib Pajak merasa diperlakukan dengan baik dan diberikan penjelasan yang memadai sehingga koreksi yang dilakukan oleh Fungsional Pemeriksa dapat disetujui oleh Wajib Pajak.

\section{Kesadaran dan Pemahaman Warga Negara}

Kesadaran dan pemahaman warga negara terhadap peraturan perpajakan berhubungan dengan budaya yang dianut oleh Wajib Pajak (legal culture) dan integritas petugas pajak (legal structure). Dalam Gambar 7. Model Kepatuhan ATO, ada beberapa tingkat kesadaran yang dianut oleh Wajib pajak. Apabila Wajib Pajak memiliki kesadaran yang tinggi untuk patuh, maka seharusnya DJP memberikan kemudahan dalam pemenuhan kewajiban perpajakannya. Di tingkat berikutnya, Wajib Pajak mencoba untuk patuh, tetapi tidak dapat menyusun SPT dengan baik, maka DJP memberikan bimbingan untuk membantu menyusun SPT dengan benar. Di tingkat berikutnya, Wajib Pajak tidak ingin patuh dengan mencoba mengurangi beban pajak melalui tax planning, maka DJP harus dapat mendeteksi kemungkinan adanya pelanggaran peraturan perundang-undangan dalam pelaksanaan tax planning tersebut, baik melalui himbauan dan/atau pemeriksaan. Di tingkat terakhir, Wajib Pajak teridentifikasi tidak patuh, maka DJP harus melakukan penegakan hukum yang tegas terhadap Wajib pajak tersebut, baik melalui pemeriksaan, atau pemeriksaan bukti permulaan dan/atau penyidikan.

Identifikasi tingkat kesadaran dan pemahaman Wajib Pajak terhadap peraturan perpajakan menjadi sangat penting bagi DJP, karena akan menentukan tindakan apa yang akan diambil oleh DJP untuk meningkatkan kepatuhan Wajib Pajak dan penerimaan negara di sektor perpajakan.

\section{Kualitas Petugas Pajak}

Kualitas petugas pajak akan menentukan keberhasilan DJP dalam mengumpulkan penerimaan negara di sektor perpajakan. Dalam pemeriksaan pajak, kualitas Fungsional Pemeriksa akan menentukan kualitas pemeriksaan. Kualitas Fungsional Pemeriksa utamanya dipengaruhi oleh tingkat pendidikan. Dari Gambar 8, dapat diketahui bahwa sebanyak 61,09\% Fungsional Pemeriksa di DJP memiliki gelar Sarjana Strata Satu (S1) sehingga dianggap telah mendapatkan pendidikan formal yang mencukupi. Namun pendidikan formal ini juga harus dilengkapi dengan pelatihan-pelatihan terkait hard dan soft competency.

Fungsional Pemeriksa yang berkualitas adalah Fungsional Pemeriksa yang profesional (bekerja tuntas dan akurat berdasarkan kompetensi terbaik dengan penuh tanggung jawab dan komitmen yang tinggi) dan berintegritas (berpikir, berkata, berperilaku dan bertindak dengan baik dan benar serta memegang teguh kode etik dan prinsip-prinsip moral) sehingga mampu meyakinkan Wajib Pajak untuk menyetujui hasil pemeriksaan.

\section{Hambatan-Hambatan dalam Pelaksanaan Pemeriksaan Pajak}

Dalam pelaksanaan pemeriksaan pajak, seringkali ditemui hambatan-hambatan yang mengakibatkan hasil pemeriksaan tidak sesuai 
dengan yang direncanakan. Ada beberapa hambatan yang dapat diidentifikasi, yaitu:

\section{Target Penerimaan Negara di Sektor Perpajakan yang Tidak Sesuai dengan Faktor-Faktor yang Realistis}

Selama lima tahun terakhir, yaitu dari tahun 2010 s.d. 2014, penerimaan perpajakan tidak pernah tercapai. Rata-rata pencapaian selama lima tahun tersebut sebesar $95,8 \%$. Berdasarkan hasil wawancara dan analisa data, permasalahan tidak tercapainya penerimaan selama lima tahun terakhir dapat diidentifikasi menjadi empat faktor, yaitu: (1) Perencanaan. Selama ini, penentuan target penerimaan pajak menggunakan metode incremental, yaitu realisasi penerimaan tahun lalu ditambah dengan pertumbuhan alami seperti inflasi, exchange rate, interest rate, dan growth of economy serta perkiraan extra effort yang akan dilakukan oleh DJP. Pertumbuhan alami dipengaruhi oleh faktor-faktor ekonomi baik makro maupun mikro sehingga dianggap sebagai faktor eksternalitas. Perkiraan extra effort dipengaruhi oleh kebijakan internal DJP dalam mencapai penerimaan pajak. Tingginya perencanaan penerimaan ini juga disebabkan oleh kenaikan pengeluaran negara dalam APBN. Pajak menjadi alternatif yang paling menguntungkan bagi negara dibandingkan pembiayaan lainnya seperti utang luar negeri karena negara tidak terbebani dengan biaya bunga. Tidak tercapainya penerimaan dalam lima tahun ini salah satunya disebabkan oleh perencanaan yang tidak sesuai dengan faktorfaktor yang acceptable, artinya penentuan target tidak realistis karena tidak sesuai dengan pertumbuhan alamiah dan prognosa extra effort yang dilakukan DJP. Sebagai contoh, apabila kenaikan target penerimaan tahun ini sebesar $36 \%$ sedangkan pertumbuhan alamiahnya sebesar $11 \%$, maka seharusnya extra effort yang dilakukan DJP minimal sebesar $25 \%$. Namun, rata-rata kinerja yang dilakukan DJP selama ini di bawah $10 \%$ sehingga penerimaan pajak akan tidak tercapai, kecuali ada perubahan tax policy, tax administration dan effort yang signifikan sehingga gap sebesar $25 \%$ dapat terpenuhi; (2) Sistem Pajak. Sistem pajak terdiri atas legal substance, legal structure dan legal culture. Legal substance berkaitan dengan kebijakan dan peraturan perpajakan, legal structure terkait dengan sumber daya anusia yang berhubungan dengan pajak dan legal culture terkait dengan budaya yang dianut masyarakat terkait perpajakan. Terkait legal substance, perlu dilihat apakah ada perubahan peraturan yang dapat menyebabkan tidak tercapainya penerimaan, seperti penambahan fasilitas atau insentif perpajakan, penambahan faktor pengurang dalam penghitungan pajak dan pengurangan obyek penghasilan yang dapat dikenakan pajak. Pemberian fasilitas tax holiday atau tax allowance, penambahan Penghasilan Tidak Kena Pajak (PTKP) dan dihapuskannya jasa catering sebagai obyek PPN merupakan beberapa contoh legal substance yang dapat mengurangi penerimaan pajak. Terkait legal structure, perlu dilihat apakah ada 'kebocoran' penerimaan pajak yang dilakukan oleh petugas. Petugas disini bukan hanya petugas pajak tetapi seluruh petugas yang terlibat dalam penegakan hukum di bidang perpajakan seperti polisi, jaksa dan hakim. Profesionalitas dan integritas merupakan dua kata kunci yang harus dipegang setiap petugas sehingga dapat meminimalisasi 'kebocoran' penerimaan pajak. Legal culture mencerminkan budaya dan tata nilai yang dianut oleh masyarakat secara umum dan Wajib Pajak secara khusus, dalam menyikapi urusan pajak. Apabila Wajib Pajak menganggap petugas pajak dalam diajak 'bermain' atau dengan kata lain dapat disuap, maka Wajib Pajak akan melakukan itu untuk meringankan beban pajaknya. Secara alami, tidak ada orang yang secara sukarela dipungut pajak dari penghasilan yang diterimanya, sehingga setiap orang akan berusaha agar dapat meminimalkan beban pajak yang harus dibayarnya; (3) Kebijakan Pemerintah. Kebijakan pemerintah disini merupakan kebijakan pemerintah yang tidak terkait dengan perpajakan, seperti kebijakan ekspor impor, kebijakan perdagangan, kebijakan investasi dan sebagainya. Kebijakan pemerintah dapat mempengaruhi penerimaan pajak, sebagai contoh pengenaan bea keluar terhadap komoditas pertambangan seperti 
batubara dan pertanian seperti kelapa sawit akan berdampak pada penerimaan pajak. Wajib Pajak akan berusaha menjaga margin keuntungan perusahaan sehingga penambahan beban bea keluar akan membuat Wajib Pajak berusaha menurunkan pajak yang harus dibayar; (4) Kebijakan Eksternal. Kebijakan eksternal yang dimaksud adalah kebijakan dari luar negeri yang dapat menggerus penerimaan pajak. Kebijakan eksternal merupakan faktor yang uncontrollable sehingga tidak dapat dikendalikan oleh pemerintah, khususnya DJP. Sebagai contoh, kebijakan China mengurangi impor kelapa sawit membuat permintaan minyak kelapa sawit dari China menurun sehingga pendapatan Wajib Pajak yang bergerak di industri kelapa sawit berkurang. Dengan berkurangnya pendapatan Wajib Pajak maka berkurang juga pajak yang disetor sehingga penerimaan pajak dari sektor ini menjadi menurun: (4.a) Aspek Peraturan Perundang-undangan. Peraturan perpajakan yang baik harus memiliki kejelasan, kepastian, dan kesederhanaan sehingga tidak menimbulkan multi tafsir. Peraturan yang multi tafsir membuka celah bagi petugas pajak dan Wajib Pajak untuk melakukan negosiasi dan menjadi loophole untuk mengurangi beban pajak melalui tax planning baik dengan tax avoidance maupun tax evasion. Peraturan perpajakan yang multi tafsir dapat menjadi hambatan dalam pemeriksaan karena akan menimbulkan kebingungan bagi Fungsional Pemeriksa Pajak dalam menghitung pajak yang seharusnya dibayar. Sebagai contoh, biaya angkutan kapal dalam pertambangan batubara dapat termasuk dalam kategori $\mathrm{PPh}$ Pasal 23 atau PPh Pasal 15. Tidak ada kriteria yang jelas yang dapat membedakan apakah biaya angkutan kapal tersebut termasuk jasa penunjang pertambangan (jasa pengangkutan/sistem transportasi) atau termasuk pelayaran dalam negeri. Ketidakjelasan ini dapat menyebabkan Fungsional Pemeriksa salah dalam menetapkan tarif sehingga tujuan pemeriksaan untuk mengoptimalkan penerimaan negara tidak tercapai; (4.b) Data. Data (baik data internal maupun data eksternal) merupakan elemen yang penting dalam sistem self assessment. Data eksternal digunakan oleh
DJP sebagai pembanding SPT yang dilaporkan oleh Wajib Pajak. Namun, kenyataannya Fungsional Pemeriksa tidak didukung oleh eksternal yang memadai sehingga sulit menguji kebenaran SPT yang dimasukan oleh Wajib Pajak. Selain itu, data internal DJP juga belum terintegrasi dan hanya dapat diakses secara terbatas oleh Fungsional Pemeriksa. Peraturan Pemerintah Nomor 31 Tahun 2012 sebagai tindak lanjut dari Pasal 35A UU KUP juga belum optimal dalam mengumpulkan data dan informasi terkait perpajakan. Berdasarkan Pasal 35A UU KUP, instansi, lembaga, asosiasi dan pihak lain (ILAP) diwajibkan memberi data dan informasi yang berkaitan dengan perpajakan kepada DJP. Namun hingga saat ini belum semua ILAP telah menyerahkan data dan informasi tersebut karena PP Nomor 31 Tahun 2012 mengamanahkan penerbitan Peraturan Menteri Keuangan untuk dapat menetapkan ILAP dan jenis data yang wajib diberikan oleh DJP. Sampai dengan Oktober 2014, baru 61 ILAP yang telah ditetapkan untuk memberikan data dan informasi terkait perpajakan. Sebagai perbandingan, di Belanda Pemeriksa Pajak sudah dapat memperkirakan koreksi yang akan dilakukan sebelum turun ke lapangan untuk melakukan pemeriksaan. Data juga berperan dalam menyeleksi Wajib Pajak yang akan diperiksa dan mengetahui berapa tax gap yang dimiliki oleh Wajib Pajak; (4.c) Beban Pemeriksaan Pajak yang Tinggi. Dari 67.564 Surat Perintah Pemeriksaan (SP2) yang diterbitkan di tahun 2013, persentase pemeriksaan rutin sebesar $60,3 \%$ sedangkan pemeriksaan khusus sebesar $34,6 \%$, sisanya sebesar 5,1 pemeriksaan untuk tujuan lain. Pemeriksaan rutin adalah pemeriksaan yang dilakukan untuk SPT Lebih bayar yang diajukan pengembalian oleh Wajib Pajak. Banyaknya pemeriksaan rutin menyebabkan beban pemeriksaan meningkat sehingga Fungsional Pemeriksa tidak memiliki waktu yang cukup untuk melakukan pengujian. Akibatnya, pemeriksaan yang dilakukan menjadi tidak mendalam sehingga pemeriksaan hanya sekedar memenuhi aspek formal namun mengabaikan materi pemeriksaan sehingga tidak dapat menghasilkan koreksi yang dapat 
meningkatkan penerimaan pajak; (4.d) Sumber Daya Manusia. Pada tahun 2013, jumlah Fungsional Pemeriksa sebanyak 4.765 pegawai sedangkan jumlah Wajib Pajak terdaftar yang wajib menyampaikan SPT Tahunan sebanyak 28.013.310 sehingga rasio antara Fungsional Pemeriksa terhadap Wajib Pajak sebesar 1:5.879. Rasio ini masih belum ideal sehingga DJP membutuhkan lebih banyak Fungsional Pemeriksa agar dapat melakukan penegakan hukum lebih optimal. Keterbatasan jumlah Fungsional Pemeriksa ini juga menyebabkan audit coverage ratio hanya sebesar 0,29\%, artinya baru 0,29\% Wajib Pajak yang diperiksa dari seluruh Wajib Pajak terdaftar yang wajib menyampaikan SPT. Dari sisi kualitas SDM, masih banyak Fungsional Pemeriksa yang belum memiliki kompetensi yang memadai. Indikasinya adalah masih banyak hasil pemeriksaan yang kalah di Pengadilan Pajak. Berdasarkan statistik tahun 2013, terhadap hasil pemeriksaan yang diajukan banding oleh Wajib Pajak, yang putusannya mengabulkan sebagian dan/atau mengabulkan seluruhnya, sebanyak 4.278 kasus atau $58 \%$ dari total 7.376 putusan Pengadilan Pajak. Fungsional Pemeriksa membutuhkan kompetensi dan keahlian yang dapat menyakinkan Wajib Pajak untuk tidak mengelak dan menyetujui hasil temuan pemeriksaan. Dengan disetujuinya hasil temuan pemeriksaan, maka diharapkan penerimaan pajak dari hasil pemeriksaan dapat meningkat; (4.e) Sarana dan Prasarana. Dalam melakukan pemeriksaan pajak, Fungsional Pemeriksa perlu didukung oleh sarana dan prasarana yang dapat memperlancar pelaksanaan pemeriksaan. Tanpa dukungan sarana dan prasarana yang memadai, pelaksanaan pemeriksaan akan terhambat dan sulit mencapai tujuan pemeriksaan. Sarana dan prasarana yang dapat mendukung pelaksanaan pemeriksaan antara lain kendaraan dinas dan dana operasional. Di beberapa KPP, Fungsional Pemeriksa tidak mendapatkan kendaraan dinas untuk operasional. Apabila Fungsional Pemeriksa akan meminta data ke Wajib Pajak, Fungsional Pemeriksa akan meminjam kendaraan dinas kepada pejabat struktural. Hal ini dapat menghambat pemeriksaan karena tidak setiap saat kendaraan dinas yang dipegang oleh pejabat struktural tersedia. Terbatasnya dana operasional juga dapat menghambat pemeriksaan terutama bagi Fungsional Pemeriksa yang bertugas di luar pulau Jawa khususnya yang berada di remote area. Dalam melakukan pemeriksaan, tak jarang Fungsional Pemeriksa harus melakukan perjalanan jauh dan menginap di suatu daerah. Biaya perjalanan tersebut ditanggung negara dalam bentuk dana Surat Perintah Perjalanan Dinas (SPPD). Namun, dana SPPD ini peruntukannya tidak hanya untuk Fungsional Pemeriksa tetapi juga untuk pegawai lainnya seperti pejabat struktural eselon III dan IV, Account Representative, serta pelaksana lainnya. Apabila dana SPPD ini sudah habis, maka Fungsional Pemeriksa akan sulit melakukan permintaan data ke Wajib Pajak, terutama Wajib Pajak yang lokasinya jauh.

\section{Solusi dalam Mengatasi Hambatan- Hambatan Pemeriksaan Pajak}

Terhadap hambatan-hambatan tersebut di atas, perlu dicarikan solusi untuk mengatasi hambatan-hambatan tersebut. Solusi-solusi yang diajukan berdasarkan identifikasi hambatan pemeriksaan pajak antara lain:

\section{Target Penerimaan Negara di Sektor Perpajakan yang Tidak Sesuai dengan Faktor-Faktor yang Realistis}

Salah satu penyebab tidak tercapainya penerimaan negara di sektor perpajakan adalah target penerimaan yang terlalu tinggi sehingga dalam kondisi normal, penerimaan tidak akan tercapai. Untuk mengatasinya, perlu disusun metode penyusunan target penerimaan yang lebih realistis dengan mengakomodasi faktorfaktor yang mempengaruhi penerimaan seperti pertumbuhan alami (interest rate, exchange rate, growth of economy dan inflasi) dan extra effort yang dilakukan oleh DJP serat memperhatikan kebijakan pemerintah lainnya yang tidak terkait pajak dan kebijakan negara lain.

Pada akhir tahun, DJP akan menyusun realisasi penerimaan dan prognosa penerimaan di tahun mendatang. Data prognosa ini dapat 
digunakan sebagai acuan perkiraan realisasi penerimaan negara di sektor perpajakan dengan menganggap faktor pertumbuhan alami sebagai ceteris paribus. Namun, Anggaran Pendapatan dan Belanja Negara (APBN) di Indonesia disusun dengan prioritas menghitung pengeluaran terlebih dahulu sehingga penerimaan akan menyesuaikan dengan pengeluaran yang ditetapkan. Penerimaan negara di sektor perpajakan menjadi alternatif yang paling masuk akal untuk menutupi defisit APBN karena tidak menimbulkan biaya tambahan lainnya seperti bunga dan dapat meningkatkan kemandirian bangsa: (1) Aspek Peraturan Perundangundangan. Untuk mengatasi peraturan perpajakan yang multi tafsir, perlu disusun peraturan perundang-undangan yang memberikan kejelasan, kepastian dan kesederhanaan sehingga tidak ada sengketa peraturan yang terjadi, baik antar pegawai DJP maupun antara pegawai DJP dengan Wajib Pajak. Apabila terjadi multi tafsir peraturan, perlu ditunjuk satu pihak yang dapat memberikan penegasan terhadap peraturan tersebut sehingga terjadi persamaan persepsi, terutama di internal DJP. Dengan adanya persamaan persepsi tersebut, diharapkan sengketa terkait peraturan dapat diminimalisasi sehingga Wajib Pajak menjadi lebih patuh. Peningkatan kepatuhan Wajib Pajak diharapkan akan berimbas pada peningkatan penerimaan pajak; (2) Data. Terkait hambatan data, ada beberapa usulan solusi yang diharapkan dapat mengatasi hambatan tersebut, yaitu: (2.a) ptimalisasi peran PP Nomor 31 Tahun 2012 dalam mengumpulkan data dan informasi terkait perpajakan dengan menetapkan prioritas ILAP dan jenis data yang dapat membantu pelaksanaan pemeriksaan pajak; (2.b) Dukungan penyediaan data yang terintegrasi kepada Fungsional Pemeriksa sebelum melakukan pemeriksaan sehingga Fungsional Pemeriksa dapat mengetahui titiktitik kritis (critical point) pemeriksaan yang diharapkan dapat meningkatkan kepatuhan Wajib Pajak dan menggali potensi pajak lebih efektif dan efisien; (2.c) Beban Pemeriksaan Pajak yang Tinggi. Beban pemeriksaan yang tinggi disebabkan oleh banyaknya pemeriksaan rutin untuk menguji kebenaran pelaporan SPT Lebih Bayar yang dimintakan restitusi oleh Wajib Pajak. Untuk mengurangi beban pemeriksaan pajak yang tinggi perlu disusun prioritas SPT Lebih Bayar Wajib Pajak yang akan diperiksa. Pasal 17C UU KUP mengatur proses pengembalian lebih bayar untuk Wajib Pajak dengan kriteria tertentu dapat dilakukan dengan penelitian, sedangkan Pasal 17D UU KUP mengatur proses pengembalian lebih bayar untuk Wajib Pajak yang memenuhi persyaratan tertentu dapat dilakukan dengan penelitian. Pasal 17C dan Pasal 17D UU KUP memberikan alternatif selain pemeriksaan pajak untuk menyelesaikan proses pengembalian SPT Lebih Bayar yang diajukan oleh Wajib Pajak sehingga SP2 yang diterbitkan untuk pemeriksaan rutin menjadi berkurang. Dengan berkurangnya jumlah pemeriksaan rutin, maka diharapkan Fungsional Pemeriksa dapat lebih berkonsentrasi ke pemeriksaan yang dapat meningkatkan kepatuhan Wajib Pajak dan penerimaan pajak; (3) Sumber Daya Manusia. Terkait hambatan sumber daya manusia, ada dua usulan solusi yang dapat mengatasi hambatan tersebut, yaitu: (3.a) Perlu ada penambahan jumlah Fungsional Pemeriksa yang profesional dan berintegritas, baik melalui perekrutan dari luar DJP ataupun dari internal DJP. Penambahan jumlah Fungsional Pemeriksa ini akan meningkatkan audit coverage ratio sehingga jumlah Wajib Pajak yang diperiksa menjadi meningkat. Dengan adanya peningkatan jumlah Wajib Pajak yang diperiksa dan penyeleksian Wajib Pajak yang tepat, maka akan memberikan deterrent effect berupa peningkatan kepatuhan Wajib Pajak yang pada akhirnya akan meningkatkan penerimaan pajak; (3.b) Perlu ada penyelenggaraan pendidikan dan pelatihan, baik hard maupun soft competency, yang berkelanjutan dan merata. Hard competency berkaitan dengan upgrading pengetahuan perpajakan, teknologi informasi, metode dan teknik pemeriksaan. Soft competency berkaitan dengan kompetensi yang harus dimiliki oleh Fungsional Pemeriksa untuk mendukung pelaksanaan pemeriksaan. Soft competency ini diantaranya kemampuan menyakinkan Wajib Pajak (negotiation and communication skill), integritas, manajemen waktu dan motivasi; (4) 
Sarana dan Prasarana. Untuk meningkatkan dukungan sarana dan prasarana dalam pelaksanaan pemeriksaan, ada dua usulan solusi, yaitu: (4.a) Dari seluruh kendaraan dinas yang dimiliki oleh Kanwil DJP maupun KPP, perlu ada kendaraan dinas yang dapat digunakan setiap saat oleh Fungsional Pemeriksa yang dalam melaksanakan pemeriksaan. Apabila kendaraan dinas yang dimiliki oleh Kanwil DJP atau KPP terbatas, maka alternatifnya adalah menyewa mobil secara tahunan. Secara aturan, Kanwil DJP dan KPP diperbolehkan menyewa kendaraan apabila kendaraan dinas yang dimilikinya tidak mencukupi untuk pelaksanaan pekerjaan. Dengan adanya kendaraan dinas yang khusus digunakan oleh Fungsional Pemeriksa, maka diharapkan pelaksanaan pemeriksaan menjadi lancar sehingga dapat mencapai tujuan pemeriksaan yang diharapkan; (4.b) Perlu ada pemisahan dana SPPD untuk Fungsional Pemeriksa. Pemeriksaan pajak merupakan salah satu pilar law enforement, maka perlu ada dana khusus yang dapat mendukung pelaksanaan law enforcement tersebut. Dengan dukungan dana operasional yang meningkat, secara kuantitas dan kualitas diharapkan pemeriksaan pajak dapat meningkat.

\section{Kesimpulan}

Pemeriksaan Pajak yang dapat mengoptimalkan penerimaan negara di sektor perpajakan dipengaruhi oleh beberapa faktor, yaitu: (1) Peraturan perundang-undangan yang memberikan kejelasan, kepastian dan kesederhanaan yang dapat mengurangi sengketa peraturan; (2) Kebijakan pemerintah dalam mengimplementasikan peraturan perundang-undangan secara rinci, transparan dan equal treatment; (3) Sistem administrasi yang memberikan fungsi penyuluhan, pelayanan dan pengawasan serta sistem informasi yang dapat membantu DJP menyeleksi Wajib Pajak yang diperiksa; (4) Pelayanan prima dalam pelaksanaan pemeriksaan pajak, diantaranya memperlakukan Wajib Pajak dengan baik dan memberikan penjelasan yang memadai; (5) Tingkat kesadaran dan pemahaman Wajib Pajak terhadap peraturan perpajakan; dan (6)
Fungsional Pemeriksa yang profesional dan berintegritas sehingga mampu meyakinkan Wajib Pajak untuk menyetujui hasil pemeriksaan.

Terdapat beberapa hambatan dalam pelaksanaan pemeriksaan pajak, yaitu: (1) Target penerimaan negara di sektor perpajakan yang tidak realistis sehingga sulit tercapai; (2) Peraturan perpajakan yang multi tafsir sehingga menjadi celah bagi Wajib Pajak untuk melakukan tax avoidance dan tax evasion; (3) Terbatasnya data eksternal sebagai bahan pembanding dan belum terintegrasinya data internal yang dimiliki oleh DJP; (4) Beban pemeriksaan rutin yang tinggi sehingga Fungsional Pemeriksa tidak memiliki waktu yang cukup untuk melakukan pengujian secara mendalam; (5) Kurangnya kuantitas dan kualitas Fungsional Pemeriksa Pajak; dan (6) Kurangnya dukungan kendaraan dinas dan dana operasional dalam pelaksanaan pemeriksaan pajak.

Solusi untuk mengatasi hambatan-hambatan tersebut yaitu: (1) Penyusunan target penerimaan harus lebih realistis dengan mengakomodasi faktor-faktor yang mempengaruhi penerimaan seperti pertumbuhan alami dan extra effort yang dilakukan oleh DJP serta memperhatikan kebijakan pemerintah lainnya yang tidak terkait pajak dan kebijakan negara lain; (2) Peraturan perpajakan harus disusun dengan memperhatikan prinsip kejelasan, kepastian dan kesederhanaan sehingga dapat meminimalisasi munculnya penafsiran yang berbeda-beda (multi tafsir); (3) Optimalisasi PP Nomor 31 tahun 2012 untuk mengumpulkan lebih banyak data dan informasi terkait perpajakan serta penyediaan data internal yang terintegrasi sebelum pelaksanaan pemeriksaan; (4) Mengurangi pemeriksaan rutin dengan memproses pengembalian lebih bayar menggunakan Pasal 17C dan Pasal 17D UU KUP; (5) Penambahan kuantitas dan kualitas Fungsional Pemeriksa Pajak; dan (6) Penyediaan kendaraan dinas untuk pelaksanaan pemeriksaan dan 
pemisahan dana operasional pemeriksaan pajak.

\section{Saran}

Perlu disusun metode penentuan target penerimaan dengan memperhitungkan realisasi penerimaan tahun lalu, pertumbuhan alami, dan rata-rata extra effort yang dilakukan oleh DJP serta faktor eksternal yang dapat mempengaruhi penerimaan: (a) Dalam penyusunan peraturan perpajakan, perlu ada mekanisme yang dapat meyakinkan bahwa peraturan yang disusun telah memenuhi prinsip kejelasan, kepastian dan kesederhanaan. Apabila ada sengketa, maka perlu ditunjuk satu pihak yang dapat memberikan penegasan sehingga dapat menyamakan persepsi; (b) Perlu adanya prioritas penetapan ILAP dan jenis data yang diidentifikasi dapat mendukung pelaksanaan pemeriksaan dan optimalisasi pengolahan data yang dapat digunakan dalam pelaksanaan pemeriksaan pajak untuk mengetahui titik-titik kritis (critical point) yang perlu digali; (c) Perlu memperbanyak proses pengembalian lebih bayar dari pemeriksaan ke penelitian berdasarkan Pasal 17C dan Pasal 17D UU KUP. Mitigasi risiko dari Pasal 17C dan Pasal 17D adalah pengenaan sanksi kenaikan sebesar $100 \%$ jika terdapat bukti ketidakpatuhan; (d) Perlu penambahan jumlah Fungsional Pemeriksa yang profesional dan berintegritas serta penyelenggaraan pendidikan dan pelatihan, baik hard maupun soft competency, yang berkelanjutan dan merata; dan (e) Perlu penambahan kendaraan operasional, baik dengan pembelian ataupun sewa, dan pembuatan akun biaya perjalanan dinas tersendiri untuk pelaksanaan pemeriksaan pajak.

\section{Referensi}

Hutagaol, John. 2007. Perpajakan: Isu-isu Kontemporer. Yogyakarta: Graha Ilmu.

Rahayu, Siti Kurnia. 2010. Perpajakan Indonesia: Konsep \& Aspek Formal. Yogyakarta: Graha Ilmu.

Silalahi, Ulber. 2012. Metode Penelitian Sosial. Bandung: PT Refika Aditama.

Suparmoko, M. 2012. Keuangan Negara dalam Teori dan Praktik. Edisi Keenam. Yogyakarta: BPFE.
Undang-Undang Nomor 6 Tahun 1983 Sebagaimana Telah Diubah dengan Undang-undang Nomor 16 Tahun 2009 tentang Ketentuan Umum dan Tata Cara Perpajakan.

Peraturan Pemerintah Republik Indonesia Nomor 31 Tahun 2012 tentang Pemberian dan Penghimpunan Data dan Informasi yang Berkaitan dengan Perpajakan

Peraturan Menteri Keuangan Republik Indonesia Nomor 17/PMK.03/2013 tentang Tata Cara Pemeriksaan.

Peraturan Direktur Jenderal Pajak Nomor Per23/PJ/2013 tentang Standar Pemeriksaan.

Surat Edaran Direktur Jenderal Pajak Nomor SE-04/PJ/2012 tentang Pedoman Penyusunan Program Pemeriksaan Untuk Menguji Kepatuhan Pemenuhan Kewajiban Perpajakan.

Surat Edaran Direktur Jenderal Pajak Nomor SE-09/PJ/2012 tentang Pedoman Penyusunan Laporan Hasil Pemeriksaan Untuk Menguji Kepatuhan Pemenuhan Kewajiban Perpajakan.

Surat Edaran Direktur Jenderal Pajak Nomor SE-126/PJ/2010 tentang Pedoman Penyusunan Rencana Pemeriksaan (Audit Plan) Untuk Menguji Kepatuhan pemenuhan Kewajiban Perpajak 